\section{Studies in Progress}

Mr. Frarey is assistant librarian, Duke University Library. Miss Reed is librarian, Graduate Library School, University of Chicago.

$\mathrm{T}$

HE Following studies have been reported by librarians and library school directors. Although they have been reported to be in progress, some may have been completed since the report was made. While no claim is made that all studies of interest to college and university librarians have been included, an effort has been made to list those which appear to be of wide appeal. Because of space limitations, bibliographic compilations, indexes to periodicals, checklists and imprint inventories have been omitted. Unless another degree or designation is specified the items are all masters' theses.

\section{General Administrative Problems}

Becker, Joseph. Preliminary Consideration in the Planning of a Documentation Center. (Catholic)

Carhart, Forrest F., Jr. Study of Methods of Circulation Control in College and $\mathrm{Re}$ search Libraries. ACRL Research Planning Committee Study.

Draper, Greta. A Study of the Catholic University of America Library Handbindery. (Catholic)

Harvey, John F. Statistical Methods for Librarians. Special Study. (Parsons College)

Hodgson, James G. Cost of Interlibrary library Loans. Special Study. (Illinois)

\section{Personnel}

Harvey, John F. Mobility Among Library Administrators; an Analysis of Who's Who in Library Service. 1943 ed. Special Study. (Parsons College)

Park, Wilmer R. A Comparison of the Library Work and Academic Background of Student Assistants in Selected Departments of the University of Texas Library. (Texas)

\section{Selection and Acquisition of Printed} Materials

Elliott, Doris. University Presses in University Library Exchange Programs: Practices in Thirty-Eight Institutions Whose Presses Are Members of the Association of American University Presses. (Kentucky)

\section{Problems of Nonprint Materials}

Sears, Lawrence. Audio Materials in College and University Libraries; a Comparative Survey of Current Administrative Principles of Record Libraries in Six Major Colleges and Universities. (Catholic)

\section{Cataloging and Classification}

Cady, Lucille. Author Headings for the Official Publications of the State of Massachusetts. (Catholic)

Dornberger, Betty. Author Headings for the Official Publications of the State of Texas (Part II). (Texas)

Frarey, Carlyle J. History of Subject Analysis since 1850. D.L.S. (Columbia)

Markham, H. Rowland. An Inquiry into the Environments of Ideas. Ph.D. (Chicago)

Parks, Virginia B. Personal Contact between Cataloger and Reader in the Academic Library. (Chicago)

Smiley, Grace. Author Headings for the Official Publications of the District of Columbia. (Catholic)

Vaught, Kathryn J. Author Headings for the Official Publications of the State of Texas (Part I). (Texas)

\section{Reference and Bibliography}

Bray, Robert. Current Periodical Bibliographical Services in Science and Technology Published in the United States. (Catholic)

Brodman, Estelle. History of Medical Bibliography. Ph.D. (Columbia)

Dámaso, Consuelo. Outline of Philippine Printing from its Beginnings to the Pres- 
ent with a Checklist of Philippine Imprints. Ph.D. (Michigan)

Kepler, John. Study of References in Political Science Journals. (Chicago)

Linder, LeRoy H. History of the Development of Current National Bibliography. Ph.D. (Chicago)

Payne, Kirby. An Analysis of the Documentation of Geography Research to Determine the Serial Publications Most Frequently Used. (Catholic)

Schauber, Alice. An Analysis of the Documentation of Physics Research to Determine the Serial Publications Most Frequently Used. (Catholic)

Towery, James G. Current Sources and Problems of Indexing Religious Periodical Literature in the United States. (George Peabody)

Villalón Galdames, Alberto. Latin American Legal Bibliography. Ph.D. (Michigan)

\section{Use of the Library}

Brand, Charlotte. The Austin Public Library and the University of Texas Student. (Texas)

Evers, Madeline. An Investigation of Student Library Usage among the Recent Graduate Students of the Catholic University of America. (Catholic)

Harvey, John F. Investigation of Use Received by Books Charged out from Academic Libraries. Special Study. (Parsons College)

Marquis, Mary C. A Study of the Teaching of Library Facilities to College Students. (George Peabody)

Alston, Annie M. Materials Used in Research by Scholars in the Field of United States History. (Chicago)

Brown, Catherine. The Reserve Book Collection in College and University Libraries. (Carnegie)

Ho, Dorothy. A Survey of Farmington Plan Acquisition of French Books by Catholic University Library during I948-49. (Catholic)

Kennedy, Fenton. A Study of College and University Archives and Historical Collections and Their Relationship with College and University Library Administration. (Catholic)

McGehee, Bonnie M. The Textbook and Curriculum Library. (Texas)

Rawley, George R. The Public Services of College Libraries in Texas. (Texas)

Stewart, Alberta. The Map Collection in the College and University Library. (Carnegie)

\section{Reading Problems}

Gangwer, Catherine. Differences in the Quantity and Variety of Voluntary Reading of Students at Georgia State College for Women as Related to Differences in Background. (Emory)

\section{Historical Studies}

Barbour, Madge. A History of tine Goucher College Library, I885-1949. (Catholic)

Bidlack, Russell E. The History of the University of Michigan General Library, 18371850. Ph.D. (Michigan)

Irby, Margaret S. History of the University of New Mexico Press. (Texas)

Kephart, John E. The Development of His Majesty's Stationery Office and the U. S. Government Printing Office; a Comparative Study. Ph.D. (Michigan)

Owings, Vivian. A History of the Library of Morgan College, Baltimore, Md. (Catholic)

Vann, Sarah K. Booksellers in the Literary Culture of the Atlantic Coastal Area during the 18 th Century. Ph.D. (Chicago)

Wagner, Lloyd. The History of the Lafayette College Library, 1832-1941. (Catholic)

\section{Surveys}

Cain, Stith M. A Survey of the Libraries of Methodist Four-Year Colleges. Special Study. (Central College, Fayette, Mo.)

Stokes, Katharine M. Adequacy of the Library of Western Michigan College of Education, Kalamazoo, for a Fifth Year of Study in Education. Ph.D. (Michigan)

\section{Buildings}

Parham, Paul. A Study of Junior College Library Buildings. (Texas) 